\title{
Short Neuropeptide F Acts as a Functional Neuromodulator for Olfactory Memory in Kenyon Cells of Drosophila Mushroom Bodies
}

\author{
Stephan Knapek, ${ }^{1}$ Lily Kahsai, ${ }^{2}$ Åsa M. E. Winther, ${ }^{2}$ Hiromu Tanimoto, ${ }^{1}$ and Dick R. Nässel ${ }^{2}$ \\ ${ }^{1}$ Behavioral Genetics, Max Planck Institute of Neurobiology, Martinsried, D-82152 Germany and 2Department of Zoology, Stockholm University, S-10691 \\ Stockholm, Sweden
}

In insects, many complex behaviors, including olfactory memory, are controlled by a paired brain structure, the so-called mushroom bodies (MB). In Drosophila, the development, neuroanatomy, and function of intrinsic neurons of the MB, the Kenyon cells, have been well characterized. Until now, several potential neurotransmitters or neuromodulators of Kenyon cells have been anatomically identified. However, whether these neuroactive substances of the Kenyon cells are functional has not been clarified yet. Here we show that a neuropeptide precursor gene encoding four types of short neuropeptide $\mathrm{F}(\mathrm{sNPF})$ is required in the Kenyon cells for appetitive olfactory memory. We found that activation of Kenyon cells by expressing a thermosensitive cation channel (dTrpA1) leads to a decrease in sNPF immunoreactivity in the MB lobes. Targeted expression of RNA interference against the sNPF precursor in Kenyon cells results in a highly significant knockdown of sNPF levels. This knockdown of sNPF in the Kenyon cells impairs sugar-rewarded olfactory memory. This impairment is not due to a defect in the reflexive sugar preference or odor response. Consistently, knockdown of sNPF receptors outside the MB causes deficits in appetitive memory. Altogether, these results suggest that $\mathrm{SNPF}$ is a functional neuromodulator released by Kenyon cells.

\section{Introduction}

In insects a wide range of behaviors including olfactory learning and memory rely on a bilaterally symmetric brain structure, the mushroom bodies (MB) (Heisenberg, 2003; Davis, 2011). These prominent neuropils consist of intrinsic neurons, the Kenyon cells. Their dendrites form a globular microglomerular complex called calyx, which receives the main olfactory input from the antennal lobes via olfactory projection neurons (Stocker et al., 1990). The bundled axons of the Kenyon cells form characteristic vertical and medial substructures, the lobes (Strausfeld et al., 2003). Despite the importance of the MB, a functional neurotransmitter or neuromodulator produced by the Kenyon cells has not been conclusively identified in any insect. An immunohistochemical screen for candidate neuroactive substances identified the precursor for short neuropeptides $\mathrm{F}$ (sNPF) and its processed peptides in a majority of the Kenyon cells,

Received May 11, 2012; revised Jan. 31, 2013; accepted Feb. 8, 2013.

Author contributions: S.K., A.M.E.W., H.T., and D.R.N. designed research; S.K., L.K., and Å.M.E.W. performed research; D.R.N. contributed unpublished reagents/analytic tools; S.K., L.K., and Å.M.E.W. analyzed data; S.K., H.T., and D.R.N. wrote the paper.

This work was supported by the Swedish Research Council (621-2007-6500, D.R.N.), the Royal Swedish Academy of Science, the Carl Tryggers Foundation (A.M.E.W.), the Magnus Bergvalls Foundation (Å.M.E.W.), the Bernstein Focus Learning from Bundesministerium für Bildung und Forschung (H.T.), the Emmy-Noether Program from Deutsche Forschungsgemeinschaft (H.T.), and the Max Planck-Gesellschaft (H.T.). UAS-sNPF-RNAi and UAS-sNPF were generously provided by Dr. K. Yu (Daejeon, Korea). We are also grateful to Mikael A. Carlsson, Anja B. Friedrich, and our lab members for technical assistance, discussion, and critical reading of this manuscript.

Correspondence should be addressed to Stephan Knapek, Max-Planck-Institut für Neurobiologie, Am Klopferspitz 18, D-82152 Martinsried, Germany. E-mail: knapek@neuro.mpg.de.

L. Kahsai's present address: Division of Biological Sciences, University of Missouri, Columbia, M0 65211.

A.M.E. Winther's present address: Department of Neuroscience, Karolinska Institutet, von Eulers väg 3, S-171 77 Stockholm, Sweden.

DOI:10.1523/JNEUROSCI.2287-12.2013

Copyright $\odot 2013$ the authors $\quad 0270-6474 / 13 / 335340-06 \$ 15.00 / 0$ both in larval and adult Drosophila (Johard et al., 2008; Nässel et al., 2008). In most cases, neuropeptides act as neuromodulators (Nässel and Winther, 2010), but rarely as neurotransmitters in the strict sense. Here we quantified relative changes of sNPF levels afterinduced activation of Kenyon cells and investigated the role of sNPF and its receptor in the Kenyon cells for olfactory memory. Our findings strongly suggest that sNPF in Kenyon cells of the MB plays an important role in olfactory learning and/or retrieval, probably as an output signal from these neurons.

\section{Materials and Methods}

Fly strains. The following transgenic strains of Drosophila melanogaster were used for crosses: OK107-GAL4 (IV) (Connolly et al., 1996), MB247-GAL4 (III) (Zars et al., 2000), UAS-dicer2 (II) (Dietzl et al., 2007), UAS-sNPF-RNAi (X;II) (Lee et al., 2004), UAS-sNPF-RNAi (X), MB247-GAL80 (II) (Krashes et al., 2007), elav-GAL4 (X) (Lin and Goodman, 1994), UAS-sNPF (II;III) (Lee et al., 2004), UAS-sNPFR1-RNAi (III) (Hong et al., 2012), UAS-TrpA1 (II) (Hamada et al., 2008), NP3061-GAL4 (III) (Aso et al., 2009), and white $\left(w^{1118}\right)$. UAS-dicer2 was used together with MB247-GAL4 in all knockdown experiments and respective control experiments. All transgenes are inserted in $w^{1118}$ with a wild-type CantonS background.

Immunohistochemistry. Adult Drosophila heads were prepared for whole mount or cryosections as previously described (Nässel et al., 2008) with the following modifications. Thickness of optical and cryostat sections was $0.2-$ 0.5 and $25 \mu \mathrm{m}$, respectively. To visualize synaptic neuropil regions, mouse monoclonal antibodies for either nc82 (Hofbauer et al., 2009) or Synapsin (Klagges et al., 1996) were used (both 1:10; Developmental Studies Hybridoma Bank, Iowa City, IA). For Figure 1, $A$ and $C$, dissected brains were fixed for $30 \mathrm{~min}$ at room temperature in $4 \%$ formaldehyde in PBS with $0.1 \%$ Triton X-100 (PBS-Tx), washed with 0.3\% PBS-Tx, and stained using antiserum to a sequence of the Drosophila sNPF (rabbit, 1:4000) and antiSynapsin antiserum (mouse, 1:200). For detection of primary antiserum, Alexa 488-tagged goat anti-rabbit (1:1000; Invitrogen) and Cy3-tagged goat 

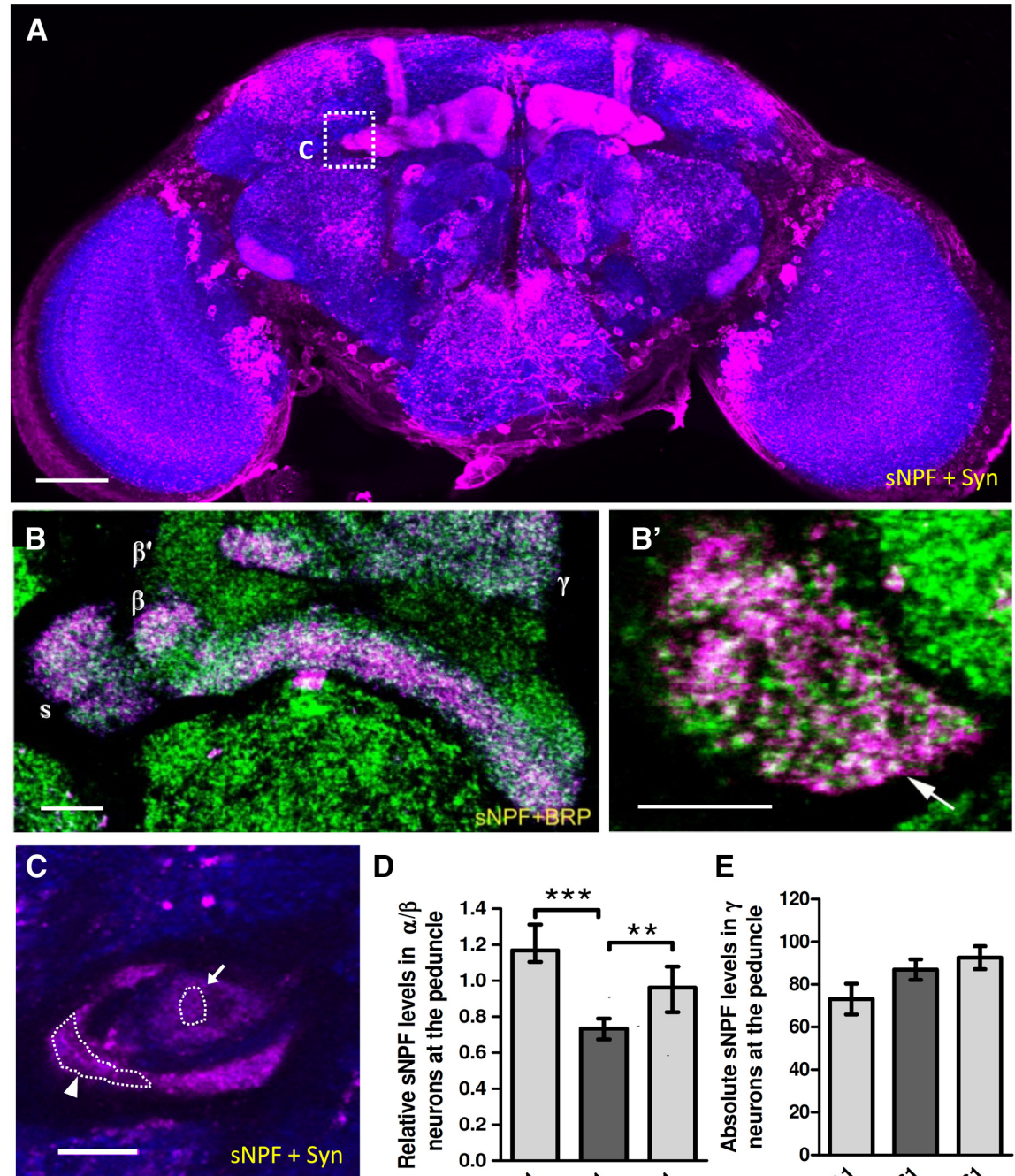

D

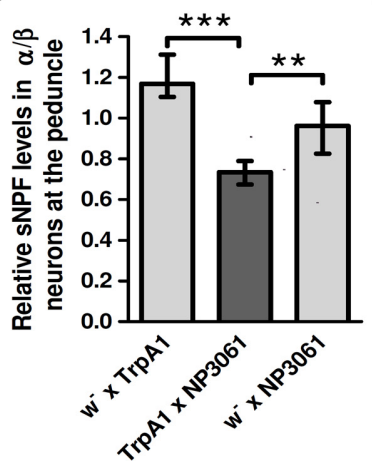

$\mathrm{E}$

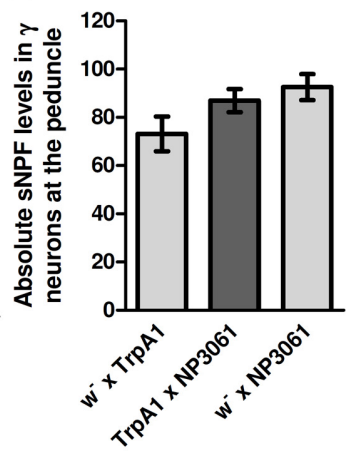

Figure 1. Decrease of sNPF upon activation of MB neurons. $A$, Double labeling of SNPF (magenta) and a ubiquitous synaptic marker Synapsin (Syn, blue) shows strong expression of the neuropeptide in the MB of a wild-type brain. Partial projection includes the anterior part of the brain. Scale bar, $50 \mu \mathrm{m}$. B, Double labeling of SNPF (magenta) and a synaptic marker Bruchpilot (BRP, green; nc82 antibody) to show relations between peptide and synapse distribution. $\gamma$-Lobe spur and $\beta$-lobe show punctate sNPF and Bruchpilot labeling, and the adjacent $\beta^{\prime}$-lobe displays no peptide labeling. $\boldsymbol{B}^{\prime}$, Higher magnification of $\mathrm{SNPF} /$ Bruchpilot double labeling in the spur region of another optical section. SNPF distribution partly matches that of synapse distribution (e.g., three punctuates at arrow). Note that part of Bruchpilot puncta originate from extrinsic neurons. Scale bars: $10 \mu \mathrm{m}$. C, A representative slice for sNPF quantification is chosen at the anterior end of the peduncle of the GAL 4 control (inset in $A$ ), showing distinct labeling of the $\alpha / \beta$ (arrow)- and $\gamma$-neurons (arrowhead). The outlined regions are used for quantification. Scale bar, $10 \mu \mathrm{m}$. D, Intensity ratio of sNPF signals in the $\alpha / \beta$-neurons (labeled by NP3061-GAL4) and the $\gamma$-neurons of the Kenyon cells (control region, not in the NP3061-GAL4 expression pattern) after 10 min thermo-activation by UAS$\operatorname{TrpA1}$. The sNPF signal is significantly reduced in the $\alpha / \beta$-neurons in the experimental group $\left({ }^{* *} p<0.01, n=19-23\right.$, bars and error bars indicate medians and quartiles, respectively). $\boldsymbol{E}$, Total intensity of sNPF signals in the $\gamma$-neurons of the Kenyon cells (control region) after 10 min at $33^{\circ} \mathrm{C}$. The groups do not differ significantly ( $p>0.05$, same data as shown in $\boldsymbol{D}$ ). Bars and error bars indicate mean and SEM, respectively.

anti-mouse antiserum (1:250; Dianova) were used. Preparations were mounted in Vectashield (Vector Laboratories) and imaged with Olympus FV-1000 or Zeiss LSM 510 confocal microscopes using $20 \times$ (NA: 0.85, oil-immersion or 0.8 , respectively) or $40 \times$ (NA: 1.0, oil immersion) objectives at an optical section thickness of $1.0 \mu \mathrm{m}$.

Thermo-activation of Kenyon cells. Crosses for thermo-activation experiments were raised at $18^{\circ} \mathrm{C}$. $\mathrm{F} 1$ progeny ( 18 to $13 \mathrm{~d}$ old $)$ was put for 10 min in empty prewarmed vials in a $33^{\circ} \mathrm{C}$ water bath and afterward transferred into new vials at room temperature. After 5 min flies were cold anesthetized and immediately dissected. All genotypes were treated in parallel and under the same experimental conditions.
Quantification of immunofluorescence. To quantify sNPF levels after thermo-activation of Kenyon cells, we measured sNPF immunofluorescence in single optical sections at the anterior end of the MB peduncle using the histogram tool of ImageJ, (National Institutes of Health, Bethesda, MD; http://rsb.info.nih.gov/ij) (Knapek et al., 2011). Fluorescence was quantified in a manually set region of interest (ROI) of the $\alpha / \beta$-neurons that were activated by UAS-TrpA1 expression driven by NP3061GAL4. To compensate for differences in immunofluorescence between different specimens the fluorescence of the thermoactivated areas ( $\alpha / \beta$-neurons) was normalized to the fluorescence of $\gamma$-neurons in the peduncle that are not part of the expression pattern of NP3061-GAL4. Fluorescence levels of sNPF after sNPF knockdown with MB247-GAL4 were measured in several manually set adjacent ROI that cover most of the targeted $\alpha$ - and $\gamma$-lobe spur and normalized to a group of neuronal cell bodies adjacent to the $\mathrm{MB}$ (in the same specimen) that are not included in the MB247-GAL4 and thus not targeted by RNA interferences (RNAi). All specimens were imaged under identical conditions.

Behavioral experiments. Crosses were raised at $25^{\circ} \mathrm{C}$. F1 progeny was collected and transferred to fresh food vials for at least $24 \mathrm{~h}$ and subsequently starved for $20-24 \mathrm{~h}$ in moistened vials. Mixed populations of 2- to 6-d-old males and females were trained and tested for $2 \mathrm{~h}$ appetitive olfactory memory as previously described (Tempel et al., 1983; Thum et al., 2007). Odors (4Methylcyclohexanol and 3-Octanol; Fluka, diluted 1:80 and 1:100 in paraffin oil) were presented in odor cups with a diameter of $14 \mathrm{~mm}$. A learning index was calculated as the mean preference of two separate groups of reciprocally trained flies. In half of the experiments the first presented odor was rewarded and in the other half, the second presented odor was rewarded (Knapek et al., 2010). Controls of odor responses were measured as previously described (Knapek et al., 2011). A negative value indicates avoidance from the odor, a performance index (PI) of zero indicates no response. Response to $2 \mathrm{M}$ sucrose was measured in a previously described setup (Schnaitmann et al., 2010). Distribution of the flies was recorded for $240 \mathrm{~s}$ at one frame per second. A PI was calculated by subtracting the number of flies on the control side from the number of flies on the sucrose side, divided by the total number of flies. To avoid any potential side preference effects, the same number of tests was made with the sucrose on the left or on the right side of the arena.

Statistics. Data were evaluated using the software Prism (GraphPad) as previously described (Kremer et al., 2010) using Kolmogorov-Smirnov and Bartlett's test, followed by one-way ANOVA or Kruskal-Wallis test. If significant at $p<0.05$, Bonferroni- or Dunn-corrected pairwise comparisons were applied; ${ }^{\star} p<0.05,{ }^{* *} p<0.01$, and ${ }^{* *} p<0.001$.

\section{Results}

Thermo-activation of Kenyon cells reduces sNPF-immunoreactive signals

The expression of $s N P F$ transcript and sNPF peptide in Kenyon cells of $\mathrm{MB}$ was demonstrated by in situ hybridization, 
immunocytochemistry and an $s N P F-$ Gal4 line (Johard et al., 2008; Nässel et al., 2008). Expression levels of the peptide differ in the $\mathrm{MB}$, being strongest in the $\alpha / \beta$-lobes, less in the $\gamma$-lobe, even weaker in the core of $\alpha / \beta$-lobes, and not detectable in the $\alpha^{\prime} / \beta^{\prime}$-lobes (Johard et al., 2008); Figs. $1 A, B, 2 A)$. Within the lobe regions sNPF peptide is distributed in a punctate fashion in the lobes and the $\gamma$-lobe spur (Fig. $1 B, B^{\prime}$ ). These puncta probably represent peptide release sites and are frequently, but not consistently colocalized with an active zone protein, Bruchpilot (Fig. 1B, $B^{\prime}$ ), suggesting that $\mathrm{sNPF}$ is commonly present near presynaptic sites throughout the lobes. Generally neuropeptides are stored in vesicles located in the perisynaptic area rather than directly in the nearby active zone (Salio et al., 2006), thus a perfect match between the two markers is not expected.

Peptide levels can be quantified by immunohistochemistry, allowing to indirectly quantifying peptide release (Han et al., 1999; Park et al., 2000; Rao et al., 2001). We used antibody staining to measure sNPF signals after induced activation in a defined subset of Kenyon cells. To specifically activate the $\alpha / \beta$-lobe neurons we expressed the thermosensitive cation channel dTRPA1 (Hamada et al., 2008) under the control of NP3061GAL4 (Aso et al., 2009) and shifted temperature to $33^{\circ} \mathrm{C}$ for $10 \mathrm{~min}$. To compensate for variability in immunofluorescence among different specimens, the fluorescence of the thermo-activated areas ( $\alpha / \beta$-neurons) was normalized to the fluorescence of a control region ( $\gamma$-neurons) in a same confocal section of the anterior peduncle (Fig. 1C). This close internal control should cancel out any potential general effects of the temperature shift on neurons. We found that thermoactivation of Kenyon cells significantly reduced sNPF levels compared with control flies (Fig. 1C,D; differences in rank sum: 17.74 and 34.36, $p<0.01$ and $p<0.001$ for comparisons of $\operatorname{TrpA1/NP3061}$ vs NP3061/+ and vs TrpA1/+, respectively. $n=19-23)$. The selected ROIs are very distinct (being located at the anterior part of the peduncle) and can be reproducibly identified among different samples. Nevertheless, we repeated the quantification by another uninformed experimenter, which yielded a similar result (data not shown). Levels of sNPF in the $\gamma$-neurons (internal control region) are not significantly different among the three tested groups (Fig. $1 E$; ANOVA, $F_{(2,58)}=2.88, p=0.064$ ). Given rapid diffusion and degradation of released peptides in the extracellular space, these data suggest activity-dependent release of sNPF from Kenyon cells.
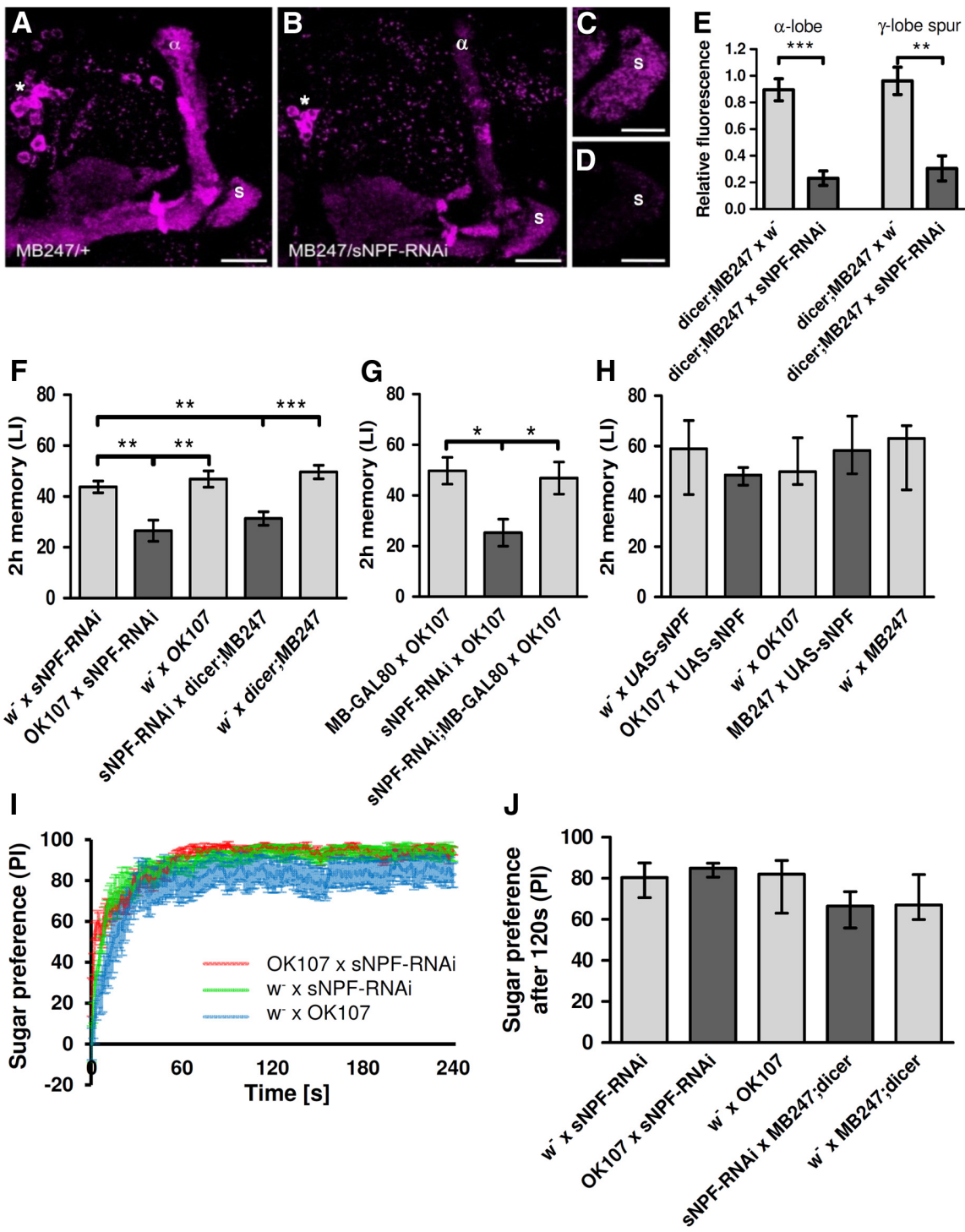

Figure 2. Knockdown of sNPF in MB, but not overexpression, leads to impaired olfactory appetitive $2 \mathrm{~h}$ memory. $\boldsymbol{A}-\boldsymbol{E}$, Reduced sNPF-immunofluorescence is observed in the MB lobes in MB247/SNPF-RNAi $(\boldsymbol{B})$ compared with control flies $(M B 247 /+; \boldsymbol{A})$. Representative images are shown. We measured immunofluorescence in the $\alpha$-lobe $(\alpha)$ and in the $\gamma$-lobe spur (s). Note that strong immunofluorescence of non-Kenyon cells (asterisks) is not affected in MB247/sNPF-RNAi. Magnification of the spur of a control brain $(\boldsymbol{C})$ and a knockdown brain $(\boldsymbol{D})$. $\boldsymbol{A}$ and $\boldsymbol{B}$ are projections of multiple MB confocal sections; $\boldsymbol{C}$ and $\boldsymbol{D}$ are single optical sections. Scale bars: $A, B, 20 \mu \mathrm{m} ; \boldsymbol{C}, \boldsymbol{D}, 10 \mu \mathrm{m}$. $\boldsymbol{E}$, Effect of the knockdown on the relative immunofluorescence in five specimens per genotype. Bars and error bars indicate mean and SEM, respectively. ${ }^{* *} p<0.001$ in $\alpha$-lobe, ${ }^{* *} p<0.01$ in $\gamma$-lobe spur. $\boldsymbol{F}$, sNPF knockdown in the MB with UAS-SNPF-RNAi expressed either in all Kenyon cells (OK107) or the $\alpha / \beta$ - and $\gamma$-neurons (MB247) leads to a significantly impaired appetitive olfactory memory tested at $2 \mathrm{~h}$ after training $\left(n=10-38,{ }^{* *} p<0.01\right)$. Bars and error bars indicate mean and SEM, respectively. G, Expression of the GAL4 repressor GAL80 under control of the MB247 promoter in the Kenyon cells rescues the memory impairment of sNPF knockdown with OK107-GAL4 $\left(n=10-14,{ }^{*} p<0.5\right)$. For this specific experiment we expressed a single copy of sNPF-RNAi (on X), which decreased memory performance to a similar level as in the previous experiments where two copies of RNAi were used. Bars and error bars indicate mean and SEM, respectively. $\boldsymbol{H}$, In contrast to the knockdown, overexpression of SNPF in the MB with neither OK107-GAL4 nor MB247-GAL4 changes $2 \mathrm{~h}$ appetitive olfactory memory $(n=8-13)$. Bars and error bars indicate median and quartile range, respectively. $I$, Normal dynamics and maintenance of sugar responses of flies with OK107-GAL4 driving SNPF-RNAi compared with control flies. Preference of 100 means that all flies are on the sugar side. $n=8-10$, means and SEM are presented. $J$, Normal response of the first 120 s of sugar presentation of $O K 107$ or MB247 driving sNPF-RNAi (for 0 K107 same data as in G). Medians with interquartile range are shown.

SNPF in the MB is required for appetitive olfactory memory To manipulate the amount of sNPF specifically in Kenyon cells, we used targeted RNAi for the sNPF precursor using the GAL4/ UAS system. Driving $S N P F-R N A i$ (two copies, $\mathrm{X}$ and II) with $M B 247-G A L 4$ in the $\alpha / \beta$ - and $\gamma$-lobes of the MB significantly reduced sNPF signal by $\sim 70 \%$ in the targeted lobes (Fig. $2 A-E$; 


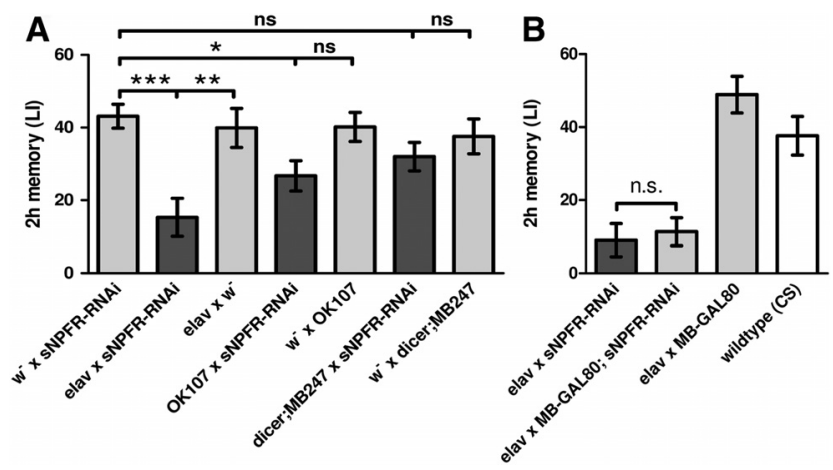

Figure 3. A receptor for sNPF is required for appetitive olfactory $2 \mathrm{~h}$ memory. $\boldsymbol{A}$, Panneuronal knockdown of the SNPF receptor (UAS-sNPFR-RNAi driven by elav-GAL4) leads to significantly impaired appetitive $2 \mathrm{~h}$ memory $\left({ }^{* *} p<0.01\right)$, whereas specific knockdown in the MB with neither OK107-GAL4 nor MB247-GAL4 significantly affects the memory ( $p>0.05$, $n=10-27$ ). Bars and error bars indicate mean and SEM, respectively. $\boldsymbol{B}$, Memory impairment after pan-neuronal knockdown of SNPFR is not significantly enhanced by expression of the GAL4 repressor GAL80 in the $\mathrm{MB}(p>0.05, n=10-12)$. Bars and error bars indicate mean and SEM, respectively.

$t_{(8)}=6.67, p<0.001$ in $\alpha$-lobes, $t_{(8)}=4.72, p=0.002$ in $\gamma$-lobe spur, $n=5$ for each genotype). Overexpression of $s N P F$ with $U A S-s N P F$ driven by OK107-GAL4 did not lead to a detectable increase of sNPF levels in the MB (data not shown).

We next addressed the function of sNPF in the MB for appetitive olfactory memory. Knockdown in all lobe systems using OK107-GAL4 significantly impaired $2 \mathrm{~h}$ memory $\left(\right.$ Fig. $2 F ; t_{(19)}=$ 3.43 and $t_{(47)}=3.70$ for comparisons of OK107/sNPF-RNA $i$ vs $O K 107 /+$ and vs $s N P F-R N A i /+$, respectively, $p<0.01, n \geq 10)$. This line strongly drives transgenic expression in most, if not all, Kenyon cells, as well as in few additional cells (Aso et al., 2009). To attribute the memory impairment to the $M B$, we tested an additional GAL4 line with overlapping expression in the $\alpha / \beta$ - and $\gamma$-neurons (MB247-GAL4) where sNPF has shown to be highly enriched (Johard et al., 2008). Similar to the sNPF knockdown by OK107-GAL4, the MB247-GAL4 significantly impaired appetitive memory (Fig. $2 F ; t_{(48)}=4.72, p<0.001$ and $t_{(65)}=3.72, p<$ 0.01 for comparisons of $M B 247 / s N P F-R N A i$ vs $M B 247 /+$ and vs $s N P F-R N A i /+$, respectively, $n \geq 21)$. We suppressed the sNPF knockdown with OK107-GAL4 only in the MB by expressing the GAL4-repressor GAL80 under control of the MB247 promoter (MB247-GAL80). GAL4 repression in the MB significantly rescued memory to control levels (Fig. $2 G ; p<0.05, t_{(22)}=2.97$ and $t_{(24)}=2.76$ for comparisons of $s N P F-R N A i / O K 107$ vs $M B-$ GAL80/OK107 and vs sNPF-RNAi;MB-GAL80/OK107, respectively, $n \geq 10$ ).

Especially because sNPF was reported to regulate feeding behavior (Lee et al., 2004), we tested whether flies with sNPF knockdown in the $\mathrm{MB}$ respond normally to the to-be-associated stimuli used in the learning paradigm. First, we examined the response to the sugar stimulus (Fig. $2 I, J$ ). None of the pairwise comparisons of sNPF knockdown in the MB with the respective controls was significantly impaired in overall sucrose preference (Fig. 2I, J; Kruskal-Wallis test $13.42, p=0.0094 ; p>0.05$ for all selected comparisons, differences in rank sums: 8.65 and 7.78 for $s N P F-$ RNAi/OK107 vs OK107/+ and vs sNPF-RNAi/+, 3.00 and -14.13 for $s N P F-R N A i / M B 247$ vs $M B 247 /+$ and vs $s N P F-$ $R N A i /+$, respectively, $n \geq 8$ ). The dynamics of sugar detection and maintenance of the choice were also indistinguishable (Fig. $2 I)$. Furthermore, the response of the knockdown flies to the used odorants (4-methylcyclohexanol and 3-octanol) was not signifi- cantly impaired compared with the corresponding genetic controls (Table 1).

Next, we tested the effect of $s N P F$ overexpression on memory. Consistent with no significant increase of sNPF immunoreactivity upon overexpression (data not shown), we observed neither impairment nor enhancement of appetitive memory in OK107/ $U A S-s N P F$ or MB247/UAS-sNPF (Fig. 2H; Kruskal-Wallis test $1.78, p>0.05, n=\geq 8$ ).

Kenyon cells may form reciprocal synapses in the trajectory of their parallel axons (Christiansen et al., 2011). To examine whether sNPF expressed in the MB targets nearby Kenyon cells, we knocked down the expression of a receptor for sNPF (sNPFR). Before local knock down in Kenyon cells, we verified the potency of the transgenic RNAi for sNPFR using a pan-neuronal driver (elav-GAL4). We found significant impairment in appetitive memory after pan-neuronal knockdown (Fig. $3 A ; t_{(18)}=3.24$, $p<0.01$ and $t_{(35)}=4.54, p<0.001$ for comparisons of elav/ $s N P F R-R N A i$ vs elav/+ and vs $s N P F R-R N A i /+$, respectively, $n \geq$ $10)$. Naive sugar and odor responses of these flies were not significantly impaired in our assay (Table 1), although a role of sNPF in feeding- and odor-driven food search has been reported earlier (Lee et al., 2004; 2008; Root et al., 2011). In contrast to the significant memory impairment after pan-neuronal knockdown, MBspecific knockdown with OK107 or MB247 did not significantly affect appetitive memory (Fig. $3 A ; p>0.05, t_{(26)}=0.89, t_{(39)}=$ 2.04 for comparisons of $M B 247 / s N P F R-R N A i$ vs $M B 247 /+$ and vs $s N P F R-R N A i /+, t_{(29)}=2.26, t_{(41)}=3.14(p>0.05)$ for OK107/sNPFR-RNA $i$ vs OK107/+ and vs $s N P F R-R N A i /+$, respectively, $n \geq 12$ ). To further support the role of $s$ NPF outside the $\mathrm{MB}$, we expressed $s N P F R-R N A i$ using elav-GAL4, but at the same time inhibited GAL4 activity in the MB by expression of MB-GAL80. Consistent with the previous data (Fig. 3A), this manipulation did not significantly improve the impaired memory performance of pan-neuronal knockdown of sNPFR (Fig. 3B; $\left.t_{(19)}=0.34, p>0.05, n \geq 10\right)$. In line with these behavioral data, we found no detectable reporter expression in Kenyon cells in sNPFR-GAL4 (data not shown) (Kahsai et al., 2012). These results together imply that $\mathrm{NNPF}$ released by Kenyon cells may be received by extrinsic neurons of the $\mathrm{MB}$ to mediate olfactory memory.

\section{Discussion}

The MBs are a prominent brain structure in insects required for olfactory learning and other complex behaviors (Heisenberg, 2003; Kahsai and Zars, 2011). Although several neurotransmitters and neuromodulators have been associated with extrinsic neurons of the MB (Liu et al., 2007, 2012; Johard et al., 2008; Tanaka et al., 2008; Liu and Davis, 2009; Aso et al., 2010; Waddell, 2010; Blenau and Thamm, 2011; Lee et al., 2011; Sejourn é et al., 2011; Aso et al., 2012), a functional neurotransmitter or neuromodulator that mediates any of the MB-dependent behaviors in intrinsic MB neurons (Kenyon cells) has not been conclusively identified yet. However, a previous study suggested a potential role of peptidergic signaling in the $\mathrm{MB}$ for olfactory learning and memory (Iliadi et al., 2008). We show that a precursor for sNPF plays an important role as a neuroactive substance for olfactory memory in Kenyon cells of the MB (Fig. $2 F, G$ ).

sNPF is expressed in $\alpha / \beta$ - and $\gamma$-lobes of the MB (Fig. $1 A, B$ ), but is undetectable in $\alpha^{\prime} / \beta^{\prime}$-lobe neurons. This suggests that different Kenyon cells may use different neuroactive substances in addition to sNPF. Furthermore, the same Kenyon cells may express potential cotransmitters together with sNPF. However, functional evidence of such neuroactive substances in the MB has 
Table 1. Odor and sugar responses of the genotypes tested in Figs. $2 \mathrm{~F}$ and $3 \mathrm{~A}$

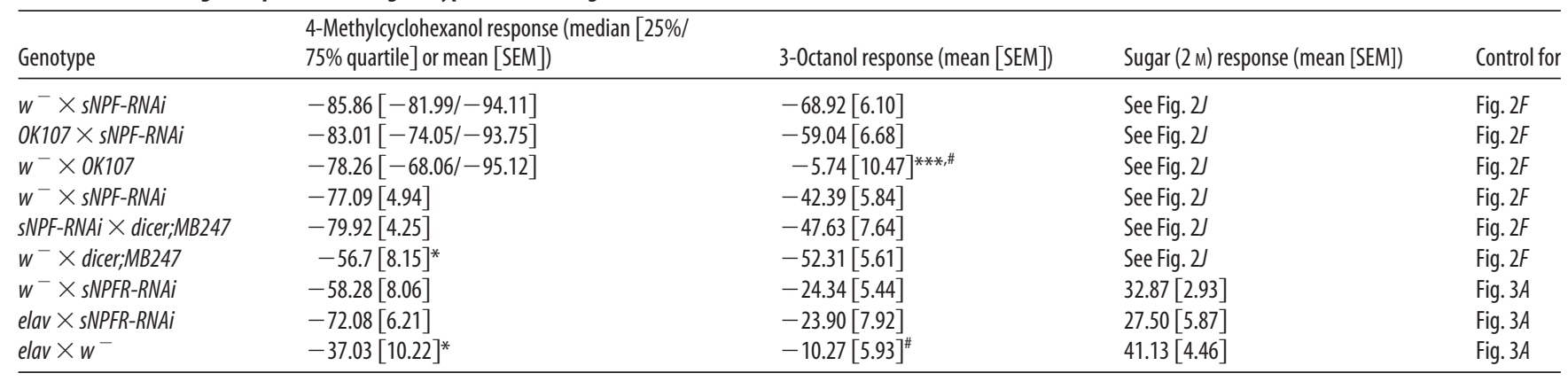

None of the experimental groups show a significantly impaired odor avoidance compared to their corresponding GAL4/+ and UAS/+ controls, although three of the control genotypes avoid one of the odors significantly less than the experimental genotype of the respective experiment (indicated by ${ }^{*} p<0.05$ and ${ }^{* *} p<0.001$ ). The 3 -octanol responses of two control genotypes were not significantly different from 0 (Wilcoxon signed rank test, $p>0.05$, indicated by $\#, n \geq 8$.

not been provided yet. In other insects neuropeptides have been detected in subpopulations of Kenyon cells: tachykinin-related peptide, FMRFamide, and gastrin cholecystokinin in honeybees (Schürmann and Erber, 1990; Strausfeld et al., 2000; Takeuchi et al., 2004) and possibly orcokinin in locust (Hofer et al., 2005). Amino acids like aspartate and taurine have been detected by immunocytochemistry in portions of the Kenyon cell populations in Drosophila, and two other insect species (Schäfer et al., 1988; Sinakevitch et al., 2001, 2008; Strausfeld et al., 2003;). Parts of the MB are shown to be glutamatergic (Bicker et al., 1988; Strausfeld et al., 2003; Sinakevitch et al., 2010). While NMDA receptors in Kenyon cells are involved in olfactory memory ( Wu et al., 2007) there is so far no conclusive evidence whether glutamate is released from the Kenyon cells or whether it represents a metabolic intermediate. Further functional evidence of these peptides and amino acids awaits further experiments. In addition, vesicular transporters for glutamate (DVGluT) as well as for amines (DVMAT) and GABA (DVGAT), seem to be absent in Kenyon cells (Chang et al., 2006; Daniels et al., 2008; Fei et al., 2010; Sinakevitch et al., 2010). Interestingly, a recent study showed that a putative vesicular transporter encoded by the portabella (prt) gene mediates courtship behavior and olfactory memory in Drosophila MB (Brooks et al., 2011). However, the target molecule of the Portabella transporter has not been identified until now.

We identified sNPF as a functional neuromodulator in Kenyon cells and the target cells are likely MB extrinsic neurons, rather than Kenyon cells themselves. These findings incite to screen for the target neurons by manipulating the sNPF receptor. This would help to identify circuits that are critical for olfactory learning. However, expression levels of sNPFR in adult Drosophila brains appear to be too low for detection with immunocytochemistry, whereas in the larvae immunolabeling was seen in unidentified neurons with processes invading the MB lobes (data not shown). Another approach to find target cells of sNPF release is knockdown of receptors for sNPF using RNAi and test for memory impairment. We verified this approach by pan-neuronal knockdown of sNPF receptors, which caused olfactory memory impairment (Fig. 3). As a first step in finding specific target neurons, we addressed whether sNPF-dependent olfactory memory involves cross talk between Kenyon cells. To this end, we knocked down the receptor specifically in the MB Kenyon cells (Fig. 3). This resulted only in a slight, but not significant, decrease in memory performance and thus is not supportive for reciprocal signaling between Kenyon cells or autocrine signaling of sNPF on these cells. Thus the neuronal target of sNPF from Kenyon cells still remains unclear for the moment, but altogether our data imply that sNPF released by Kenyon cells may be received by extrinsic neurons of the MB. Mapping neurons that require sNPF receptors for olfactory memory could be a promising future approach for finding extrinsic circuits to higher brain centers in Drosophila.

\section{References}

Aso Y, Grübel K, Busch S, Friedrich AB, Siwanowicz I, Tanimoto H (2009) The mushroom body of adult Drosophila characterized by GAL4 drivers. J Neurogenet 23:156-172. CrossRef Medline

Aso Y, Siwanowicz I, Bräcker L, Ito K, Kitamoto T, Tanimoto H (2010) Specific dopaminergic neurons for the formation of labile aversive memory. Curr Biol 20:1445-1451. CrossRef Medline

Aso Y, Herb A, Ogueta M, Siwanowicz I, Templier T, Friedrich AB, Ito K, Scholz H, Tanimoto H (2012) Three dopamine pathways induce aversive odor memories with different stability. PLoS Genet 8:e1002768. CrossRef Medline

Bicker G, Schäfer S, Ottersen OP, Storm-Mathisen J (1988) Glutamate-like immunoreactivity in identified neuronal populations of insect nervous systems. J Neurosci 8:2108-2122. Medline

Blenau W, Thamm M (2011) Distribution of serotonin (5-HT) and its receptors in the insect brain with focus on the mushroom bodies: lessons from Drosophila melanogaster and Apis mellifera. Arthropod Struct Dev 40:381-394. CrossRef Medline

Brooks ES, Greer CL, Romero-Calderón R, Serway CN, Grygoruk A, Haimovitz JM, Nguyen BT, Najibi R, Tabone CJ, de Belle JS, Krantz DE (2011) A putative vesicular transporter expressed in Drosophila mushroom bodies that mediates sexual behavior may define a neurotransmitter system. Neuron 72:316-329. CrossRef Medline

Chang HY, Grygoruk A, Brooks ES, Ackerson LC, Maidment NT, Bainton RJ, Krantz DE (2006) Overexpression of the Drosophila vesicular monoamine transporter increases motor activity and courtship but decreases the behavioral response to cocaine. Mol Psychiatry 11:99-113. CrossRef Medline

Christiansen F, Zube C, Andlauer TF, Wichmann C, Fouquet W, Owald D, Mertel S, Leiss F, Tavosanis G, Luna AJ, Fiala A, Sigrist SJ (2011) Presynapses in Kenyon cell dendrites in the mushroom body calyx of Drosophila. J Neurosci 31:9696-9707. CrossRef Medline

Connolly JB, Roberts IJ, Armstrong JD, Kaiser K, Forte M, Tully T, O’Kane CJ (1996) Associative learning disrupted by impaired Gs signaling in Drosophila mushroom bodies. Science 274:2104-2107. CrossRef Medline

Daniels RW, Gelfand MV, Collins CA, DiAntonio A (2008) Visualizing glutamatergic cell bodies and synapses in Drosophila larval and adult CNS. J Comp Neurol 508:131-152. CrossRef Medline

Davis RL (2011) Traces of Drosophila memory. Neuron 70:8-19. CrossRef Medline

Dietzl G, Chen D, Schnorrer F, Su KC, Barinova Y, Fellner M, Gasser B, Kinsey K, Oppel S, Scheiblauer S, Couto A, Marra V, Keleman K, Dickson BJ (2007) A genome-wide transgenic RNAi library for conditional gene inactivation in Drosophila. Nature 448:151-156. CrossRef Medline

Fei H, Chow DM, Chen A, Romero-Calderón R, Ong WS, Ackerson LC, Maidment NT, Simpson JH, Frye MA, Krantz DE (2010) Mutation of 
the Drosophila vesicular GABA transporter disrupts visual figure detection. J Exp Biol 213:1717-1730. CrossRef Medline

Hamada FN, Rosenzweig M, Kang K, Pulver SR, Ghezzi A, Jegla TJ, Garrity PA (2008) An internal thermal sensor controlling temperature preference in Drosophila. Nature 454:217-220. CrossRef Medline

Han W, Ng YK, Axelrod D, Levitan ES (1999) Neuropeptide release by efficient recruitment of diffusing cytoplasmic secretory vesicles. Proc Natl Acad Sci U S A 96:14577-14582. CrossRef Medline

Heisenberg M (2003) Mushroom body memoir: from maps to models. Nat Rev Neurosci 4:266-275. CrossRef Medline

Hofbauer A, Ebel T, Waltenspiel B, Oswald P, Chen YC, Halder P, Biskup S, Lewandrowski U, Winkler C, Sickmann A, Buchner S, Buchner E (2009) The Wuerzburg hybridoma library against Drosophila brain. J Neurogenet 23:78-91. CrossRef Medline

Hofer S, Dircksen H, Tollbäck P, Homberg U (2005) Novel insect orcokinins: characterization and neuronal distribution in the brains of selected dicondylian insects. J Comp Neurol 490:57-71. CrossRef Medline

Hong SH, Lee KS, Kwak SJ, Kim AK, Bai H, Jung MS, Kwon OY, Song WJ, Tatar M, Yu K (2012) Minibrain/Dyrkla regulates food intake through the Sir2-FOXO-sNPF/NPY pathway in Drosophila and mammals. PLoS Genet 8:e1002857. CrossRef Medline

Iliadi KG, Avivi A, Iliadi NN, Knight D, Korol AB, Nevo E, Taylor P, Moran MF, Kamyshev NG, Boulianne GL (2008) nemy encodes a cytochrome b561 that is required for Drosophila learning and memory. Proc Natl Acad Sci U S A 105:19986-19991. CrossRef Medline

Johard HA, Enell LE, Gustafsson E, Trifilieff P, Veenstra JA, Nässel DR (2008) Intrinsic neurons of Drosophila mushroom bodies express short neuropeptide F: relations to extrinsic neurons expressing different neurotransmitters. J Comp Neurol 507:1479-1496. CrossRef Medline

Kahsai L, Zars T (2011) Learning and memory in Drosophila: behavior, genetics, and neural systems. Int Rev Neurobiol 99:139-167. CrossRef Medline

Kahsai L, Carlsson MA, Winther AM, Nässel DR (2012) Distribution of metabotropic receptors of serotonin, dopamine, GABA, glutamate, and short neuropeptide F in the central complex of Drosophila. Neuroscience 208:11-26. CrossRef Medline

Klagges BR, Heimbeck G, Godenschwege TA, Hofbauer A, Pflugfelder GO, Reifegerste R, Reisch D, Schaupp M, Buchner S, Buchner E (1996) Invertebrate synapsins: a single gene codes for several isoforms in Drosophila. J Neurosci 16:3154-3165. Medline

Knapek S, Gerber B, Tanimoto H (2010) Synapsin is selectively required for anesthesia-sensitive memory. Learn Mem 17:76-79. CrossRef Medline

Knapek S, Sigrist S, Tanimoto H (2011) Bruchpilot, a synaptic active zone protein for anesthesia-resistant memory. J Neurosci 31:3453-3458. CrossRef Medline

Krashes MJ, Keene AC, Leung B, Armstrong JD, Waddell S (2007) Sequential use of mushroom body neuron subsets during drosophila odor memory processing. Neuron 53:103-115. CrossRef Medline

Kremer MC, Christiansen F, Leiss F, Paehler M, Knapek S, Andlauer TF, Förstner F, Kloppenburg P, Sigrist SJ, Tavosanis G (2010) Structural long-term changes at mushroom body input synapses. Curr Biol 20: 1938-1944. CrossRef Medline

Lee KS, You KH, Choo JK, Han YM, Yu K (2004) Drosophila short neuropeptide $\mathrm{F}$ regulates food intake and body size. J Biol Chem 279: 50781-50789. CrossRef Medline

Lee KS, Kwon OY, Lee JH, Kwon K, Min KJ, Jung SA, Kim AK, You KH, Tatar M, Yu K (2008) Drosophila short neuropeptide F signalling regulates growth by ERK-mediated insulin signalling. Nat Cell Biol 10:468-475. CrossRef Medline

Lee PT, Lin HW, Chang YH, Fu TF, Dubnau J, Hirsh J, Lee T, Chiang AS (2011) Serotonin-mushroom body circuit modulating the formation of anesthesia-resistant memory in Drosophila. Proc Natl Acad Sci U S A 108:13794-13799. CrossRef Medline

Lin DM, Goodman CS (1994) Ectopic and increased expression of Fasciclin II alters motoneuron growth cone guidance. Neuron 13:507-523. CrossRef Medline

Liu C, Plaçais PY, Yamagata N, Pfeiffer BD, Aso Y, Friedrich AB, Siwanowicz I, Rubin GM, Preat T, Tanimoto H (2012) A subset of dopamine neurons signals reward for odour memory in Drosophila. Nature 488: 512-516. CrossRef Medline

Liu X, Davis RL (2009) The GABAergic anterior paired lateral neuron sup- presses and is suppressed by olfactory learning. Nat Neurosci 12:53-59. CrossRef Medline

Liu X, Krause WC, Davis RL (2007) GABAA receptor RDL inhibits Drosophila olfactory associative learning. Neuron 56:1090-1102. CrossRef Medline

Nässel DR, Winther AM (2010) Drosophila neuropeptides in regulation of physiology and behavior. Prog Neurobiol 92:42-104. CrossRef Medline

Nässel DR, Enell LE, Santos JG, Wegener C, Johard HA (2008) A large population of diverse neurons in the Drosophila central nervous system expresses short neuropeptide F, suggesting multiple distributed peptide functions. BMC Neurosci 9:90. CrossRef Medline

Park JH, Helfrich-Förster C, Lee G, Liu L, Rosbash M, Hall JC (2000) Differential regulation of circadian pacemaker output by separate clock genes in Drosophila. Proc Natl Acad Sci U S A 97:3608 -3613. CrossRef Medline

Rao S, Lang C, Levitan ES, Deitcher DL (2001) Visualization of neuropeptide expression, transport, and exocytosis in Drosophila melanogaster. J Neurobiol 49:159-172. CrossRef Medline

Root CM, Ko KI, Jafari A, Wang JW (2011) Presynaptic facilitation by neuropeptide signaling mediates odor-driven food search. Cell 145:133-144. CrossRef Medline

Salio C, Lossi L, Ferrini F, Merighi A (2006) Neuropeptides as synaptic transmitters. Cell Tissue Res 326:583-598. CrossRef Medline

Schäfer S, Bicker G, Ottersen OP, Storm-Mathisen J (1988) Taurine-like immunoreactivity in the brain of the honeybee. J Comp Neurol 268:6070. CrossRef Medline

Schnaitmann C, Vogt K, Triphan T, Tanimoto H (2010) Appetitive and aversive visual learning in freely moving Drosophila. Front Behav Neurosci 4:10. Medline

Schürmann FW, Erber J (1990) FMRFamide-like immunoreactivity in the brain of the honeybee (Apis mellifera). A light-and electron microscopical study. Neuroscience 38:797-807. CrossRef Medline

Sejourn é J, Plaçais PY, Aso Y, Siwanowicz I, Trannoy S, Thoma V, Tedjakumala SR, Rubin GM, Tchénio P, Ito K, Isabel G, Tanimoto H, Preat T (2011) Mushroom body efferent neurons responsible for aversive olfactory memory retrieval in Drosophila. Nat Neurosci 14:903-910. CrossRef Medline

Sinakevitch I, Farris SM, Strausfeld NJ (2001) Taurine-, aspartate- and glutamate-like immunoreactivity identifies chemically distinct subdivisions of Kenyon cells in the cockroach mushroom body. J Comp Neurol 439:352-367. CrossRef Medline

Sinakevitch I, Sjöholm M, Hansson BS, Strausfeld NJ (2008) Global and local modulatory supply to the mushroom bodies of the moth Spodoptera littoralis. Arthropod Struct Dev 37:260-272. CrossRef Medline

Sinakevitch I, Grau Y, Strausfeld NJ, Birman S (2010) Dynamics of glutamatergic signaling in the mushroom body of young adult Drosophila. Neural Dev 5:10. CrossRef Medline

Stocker RF, Lienhard MC, Borst A, Fischbach KF (1990) Neuronal architecture of the antennal lobe in Drosophila melanogaster. Cell Tissue Res 262:9-34. CrossRef Medline

Strausfeld NJ, Homburg U, Kloppenberg P (2000) Parallel organization in honey bee mushroom bodies by peptidergic Kenyon cells. J Comp Neurol 424:179-195. CrossRef Medline

Strausfeld NJ, Sinakevitch I, Vilinsky I (2003) The mushroom bodies of Drosophila melanogaster: an immunocytological and Golgi study of Kenyon cell organization in the calyces and lobes. Microsc Res Tech 62:151169. CrossRef Medline

Takeuchi H, Yasuda A, Yasuda-Kamatani Y, Sawata M, Matsuo Y, Kato A, Tsujimoto A, Nakajima T, Kubo T (2004) Prepro-tachykinin gene expression in the brain of the honeybee Apis mellifera. Cell Tissue Res 316:281-293. CrossRef Medline

Tanaka NK, Tanimoto H, Ito K (2008) Neuronal assemblies of the Drosophila mushroom body. J Comp Neurol 508:711-755. CrossRef Medline

Tempel BL, Bonini N, Dawson DR, Quinn WG (1983) Reward learning in normal and mutant Drosophila. Proc Natl Acad Sci U S A 80:1482-1486. CrossRef Medline

Thum AS, Jenett A, Ito K, Heisenberg M, Tanimoto H (2007) Multiple memory traces for olfactory reward learning in Drosophila. J Neurosci 27:11132-11138. CrossRef Medline

Waddell S (2010) Dopamine reveals neural circuit mechanisms of fly memory. Trends Neurosci 33:457-464. CrossRef Medline

Wu CL, Xia S, Fu TF, Wang H, Chen YH, Leong D, Chiang AS, Tully T (2007) Specific requirement of NMDA receptors for long-term memory consol- 
idation in Drosophila ellipsoid body. Nat Neurosci 10:1578-1586. CrossRef Medline
Zars T, Fischer M, Schulz R, Heisenberg M (2000) Localization of a shortterm memory in Drosophila. Science 288:672-675. CrossRef Medline 